\title{
Diagonal reinforcement as strengthening to increase the stiffness and strength of concrete frame
}

\author{
Yenny Nurchasanah ${ }^{1,{ }^{*}, \text { Muhammad } \text { Ujianto }^{1} \text {, and } A b d u l \text { Rochman }}{ }^{1}$ \\ ${ }^{1}$ Engineering Faculty, Civil Engineering Department, Universitas Muhammadiyah Surakarta, \\ Indonesia
}

\begin{abstract}
Two test objects of concrete frame behavior against lateral loading were performed by applying structural analysis with the wall as diagonal reinforcement in modeling. The results of the structural analysis indicated that concrete frames with walls have better performance than concrete frames without walls. Twelve objects consisting of the frame without the wall, frame with the wall, and frames with a group of steel and bamboo as diagonal reinforcement at brick walls and concrete panel walls were tested at the laboratory with monotonic lateral forces that work parallel to the wall as the illustration of earthquake loads. The diagonal reinforcement elements can spread the force received by the wall and increase the strength of the wall as well as enhance the stiffness of the structural system at once. Bracing contributes to increasing the strength, especially in resisting the compressive forces due to the earthquake loads. Deformation occurs in the opposite direction between compression path and tension path at the diagonal area. The failure in the concrete frame can be caused by the in-plane force parallel to the wall. Bamboo is quite effective to be used as a substitute for steel reinforcement as bracing material despite its shortage of steel quality.
\end{abstract}

\section{Introduction}

Based on SNI 2847:2013, walls only function as a non-structural component instead of as a load receiver, while in structural design the wall is only assumed as a load. In fact, the interaction between walls and concrete frames is often overlooked.

Concrete panel walls became one of the advanced technological developments in precast concrete. Currently, the use of infill panel walls is widely selected and applied in construction practices rather than the use of infill brick walls. It is due to the property of panels that they have relatively light weight, therefore it will reduce the weight of a construction. With such a property, it will have positive contributions, especially in areas affected by earthquake loads, including Indonesia. In addition, this technology can reduce costs in the construction process. Moreover, another advantage of using concrete panel walls is the easy implementation of the dissembled construction.

\footnotetext{
* Corresponding author: yenny.nurchasanah@ums.ac.id
} 
Walls are a vertical part of buildings that serve to provide the boundary between a space and another space and also as the recipient of the load. The brick wall is a wall made of a concrete-block arrangement that is tied to each other with mortar to form wall areas. Meanwhile, the structural wall is a wall that is designed, calculated and used to support the weight of gravity and lateral loads.

It seems that brick walls are successfully integrated with a reinforced concrete frame during building construction, although the connection between them is not a perfect bond, still, these components will work together to receive and carry the seismic shear loads. However, because the components of the brick wall are weaker than the components of the reinforced concrete frame, the brick wall will collapse earlier than reinforced concrete frames in structural components. Wall collapse is caused by the existence of shear force.

Preliminary analysis was done to determine the behavior of the wall for concrete frame structures. Investigation of the behavior and the capacity of the concrete frame structure with the wall as the structure was done through modeling via a structural analysis computer application program. In addition, laboratory experimental analysis was carried out to identify the behavior at laboratory scales through the testing of lateral forces at concrete frame structure.

The behavior of concrete frames with walls against lateral loading has been widely investigated, some of them are: Holmes [1], Stafford and Smith [2], Mainstone and Week [3], Dawe and Seah [4], Flanagan et al. [5], Saneinejad and Hobbs [6]. Results of the study show that the concrete frame structure with the infill wall has better ductility and behavior than that with the open frame. Therefore, the strength and stiffness of the wall should be considered in the building design process.

Walls serve as the resistance of the building structure against earthquake loads. This is proven by the fact that buildings using brick walls and panel walls are more elastic in receiving earthquake loads compared to those without walls. Furthermore, it can be observed that walls have the quality of strength and stiffness which influence the behavior of the structure [7].

While building structures may suffer from heavy damage due to a powerful earthquake, there must be an assurance that they will not collapse. Damage levels must be a concern in the structure, particularly when there is a powerful earthquake that may lead to building collapse. In order to prevent building collapse, serious attention must be paid to design sufficient details in limiting structural lateral drift [8].

Non-structural components are the components of a building that do not function as the support of the main structure and can be removed, and only serves as an additional component. This component can be removed because it does not support the establishment of a building. However, the existence of non-structural components will decorate the facade of a building. Non-structural components of a building can be put on several parts, such as walls, floors, plumbing and mechanical electrical installations, doors, and windows.

In fact, the construction of walls with the brick material in high-rise buildings at earthquake-prone areas will face several obscurities. The process requires more time and workforce in which the construction of a wall with red brick at the site will lead to adverse impact on the building, such as a longer time required by construction workers and a high number of laborers. In addition, the load will be higher so that the design becomes more extravagant. The dimension of the structure will be larger, hence the susceptibility of the building during the earthquake will be relatively high.

Technique for strengthening masonry walls with bricks and panel walls have been extensively researched using various reinforcement materials such as carbon fiber reinforced polymer [9], glass fiber reinforced polymer [9-13], basalt fiber reinforced polymer [14], fabric-reinforced cementitious matrix composite [15], steel strips [16], and other bars as reinforcement. 
To overcome the weakness of brick walls, new structural components that have better characteristics than bricks are required, one of them is a replacement with precast concrete or concrete panels. It has been proven that the concrete has high compressive strength, weather resistance, abrasion resistance, easy maintenance and has a relatively low price. Indirectly, this property will also appear on concrete panel walls.

The walls are very rigid in the in-plane direction, therefore when they are exposed to powerful earthquake loads, there will be a crack in the diagonal direction accompanied by the reduction of strength and stiffness [17]. Essentially, reinforcement at diagonal areas will reduce both the compressive force and tension force at the diagonal area.

Deformation occurs due to the combination of flexural deformation and shear deformation. There are some cases where each deformation appears separately when the flexure is formed. Nevertheless, the overall deformation of the panel wall is still accurately represented by the flexure type deformation [18].

Shear deformation and forces are shown in Fig.1. The origin shear deformation requires both the top surface and the bottom surface meet the tension. There is a compressive force along the diagonal $\mathrm{AC}$ and a tension force along $\mathrm{BD}$. The element near the middle of the span is subjected to a biaxial compression tension, the state of stress. When the tensile stress in the concrete along the diagonal BD reaches the limiting tensile strength of concrete, the crack will be formed. The failure in shear is marked by the extension of the diagonal crack up to the position of the main reinforcement diagonally opposite and by the crush in the compression corners [19].

The diagonal area is an area that ensures the greatest shear force effects are characterized by the appearance of cracks or even diagonal split. Steel and bamboo as diagonal reinforcements are constructed as a group of reinforcements consisting of 4 (four) bars in a group. Bamboo is commonly chosen as an alternative reinforcement because, in addition to the natural product, it is inexpensive, easy to cultivate, and a fast-growing plant. Moreover, the utilization of bamboo can reduce the effects of global warming and its tensile strength is well-known for the construction of simple buildings.

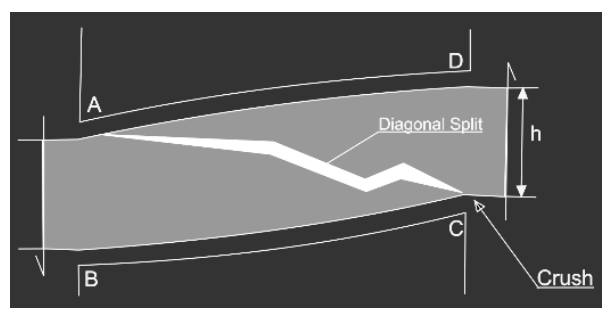

Fig. 1. Final stage: diagonal split and crush of concrete [19].

\section{Experimental details}

The reinforced concrete structure had been designed prior to the analysis of the wall behavior. The design of the reinforced concrete structure was modeled as a building open frame system, a structure that assumes that the frame will carry the dead load and live load or gravity load.

There are two structural systems, namely open frame system and infilled frame system. The open frame is a structural system consisting of a column beam frame to withstand the earthquake load, the wall is not considered to receive the earthquake load. The infilled frame is a structural system consisting of a column beam frame to withstand earthquake loads too, but the walls are considered to withstand earthquake loads. 
The structure model that was tested for the wall behavior was a concrete frame structure with a size of $4 \mathrm{~m} \times 3 \mathrm{~m} \times 3 \mathrm{~m}$ (Fig.2). The dead load consisted of self-weight beam plus a dead plate load. The dead plate load of the equivalent load consisted of the ceiling weight, ceiling holder, finishing, and tile. The live load was only from a live load of the plate. The earthquake load was measured from the calculation of total weight per floor to the determination of the earthquake force distribution. After the entire data load was collected, modeling was defined through the program structure analysis.

For the brick wall, it was modeled as a solid round shape bracing which has the characteristics of the concrete material with a specific gravity of $22.72 \mathrm{kN} / \mathrm{m} 3$ (half brick), compressive strength of concrete f'c $7 \mathrm{MPa}$ (brick wall), modulus of elasticity E 22,37 $\mathrm{MPa}$, and Poisson's ratio of 0.15 . Furthermore, the compress bracing component must be precisely defined on the program to represent the brick wall as accurately as possible.

Modeling the reinforced concrete frame structures with brick walls and concrete panel walls as components that receive lateral loads was applied into a $3 \mathrm{D}$ structural analysis program where the frame was assigned a monotonic seismic load.
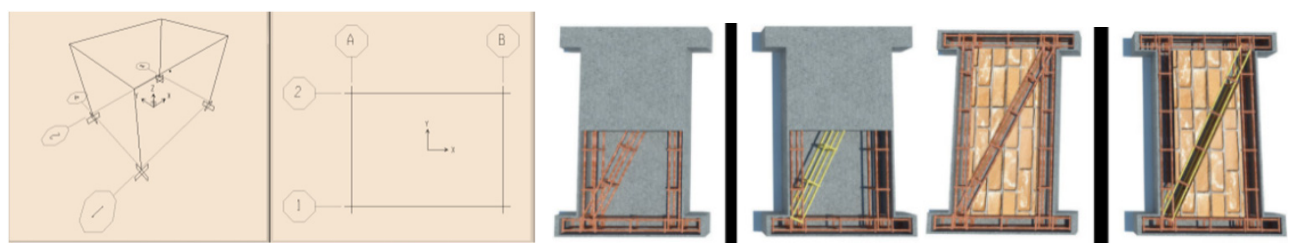

Fig. 2. Frame plan modelling $(4 \times 3 \times 3 \mathrm{~m})$ and design of concrete panel wall and brick wall.

Table 1. Specimens for Lateral Force Test of Brick Wall and Concrete Panel Wall.

\begin{tabular}{|c|c|c|c|c|c|}
\hline $\begin{array}{c}\text { Test } \\
\text { objects }\end{array}$ & $\begin{array}{l}\text { Testing } \\
\text { Type }\end{array}$ & Type of Objects & Material & $\begin{array}{c}\text { Diagonal } \\
\text { Reinforcement }\end{array}$ & $\begin{array}{l}\text { Size of } \\
\text { specimen } \\
\text { (cm) }\end{array}$ \\
\hline \multirow[b]{2}{*}{$\begin{array}{l}\text { Wall at } \\
\text { Concrete } \\
\text { Frame } \\
\text { Structure }\end{array}$} & \multirow{2}{*}{$\begin{array}{l}\text { Modelling } \\
\text { at } \\
\text { structural } \\
\text { analysis } \\
\text { program }\end{array}$} & $\begin{array}{l}\text { Concrete Frame } \\
\text { Structure }\end{array}$ & \multirow{2}{*}{$\begin{array}{c}\text { Modelling of } \\
\text { Brick Wall \& } \\
\text { Panel Wall at } \\
\text { Concrete Frame } \\
\text { Structure }\end{array}$} & $\mathrm{x}$ & \multirow[b]{2}{*}{$\begin{array}{l}\text { Beam-Column } \\
\quad(15 \times 15)\end{array}$} \\
\hline & & $\begin{array}{c}\text { Concrete Frame } \\
\text { Structure with } \\
\text { Brick Wall \& } \\
\text { Panel Wall }\end{array}$ & & $\begin{array}{c}\text { Represented by } \\
\text { Wall }\end{array}$ & \\
\hline $\begin{array}{l}\text { Concrete } \\
\text { Frame } \\
\text { Structure }\end{array}$ & \multirow{7}{*}{$\begin{array}{l}\text { Lateral } \\
\text { Force Test }\end{array}$} & $\begin{array}{l}\text { Open Frame } \\
\text { Concrete } \\
\text { Structure }\end{array}$ & $\begin{array}{c}\text { Concrete } \\
\text { materials, steel } \\
\text { reinforcement }\end{array}$ & $\mathrm{x}$ & $\begin{array}{c}\text { Frame Beam- } \\
\text { Column } \\
(15 \times 15)\end{array}$ \\
\hline \multirow{3}{*}{$\begin{array}{c}\text { Brick } \\
\text { Wall at } \\
\text { Concrete } \\
\text { Frame } \\
\text { Structure }\end{array}$} & & without bracing & \multirow{3}{*}{$\begin{array}{c}\text { Concrete } \\
\text { materials, } \\
\text { bricks, Steel } \\
\text { and Bamboo } \\
\text { reinforcement }\end{array}$} & $\mathrm{x}$ & \multirow{3}{*}{$\begin{array}{c}\text { Brick Wall } \\
(12 \times 50 \times \\
100)\end{array}$} \\
\hline & & $\begin{array}{l}\text { with Bamboo } \\
\text { Reinforcement }\end{array}$ & & Bamboo & \\
\hline & & $\begin{array}{c}\text { with Steel } \\
\text { Reinforcement }\end{array}$ & & Steel & \\
\hline \multirow{3}{*}{$\begin{array}{l}\text { Panel wall } \\
\text { at } \\
\text { Concrete } \\
\text { Frame } \\
\text { Structure }\end{array}$} & & without bracing & \multirow{3}{*}{$\begin{array}{c}\text { Concrete } \\
\text { materials, Steel } \\
\text { and Bamboo } \\
\text { reinforcement }\end{array}$} & $\mathrm{x}$ & \multirow{3}{*}{$\begin{array}{l}\text { Panel wall } \\
(7 \times 500 \times \\
100)\end{array}$} \\
\hline & & $\begin{array}{l}\text { with Bamboo } \\
\text { Reinforcement }\end{array}$ & & Bamboo & \\
\hline & & $\begin{array}{c}\text { with Steel } \\
\text { Reinforcement }\end{array}$ & & Steel & \\
\hline
\end{tabular}

The theoretical analysis was performed by using relevant parameters to predict the deformation behavior of walls on concrete structures. Laboratory experimental analysis was performed by comparing the theoretical results and laboratory results data.

Additional structural elements were treated by the addition of a group of reinforcements in the diagonal position from the end of the wall to the other side of the wall. Serving as the 
receiver of the structure lateral force, it will increase the strength of the wall and be able to increase the stiffness of the structure system.

The testing of the compressive strength of a wall was conducted by giving the load on the specimen surface until a crack is formed. According to SNI 03-4164-1996, the compressive strength of the wall is the index of compressive strength force on the wall per sectional area unit of the compressed concrete frame. The maximum tension on flexural strength was achieved on the surface of the bottom wall. According to SNI 03-4165-1996, the value of flexural strength force is the wall pairs per sectional area unit of the wall and the bent concrete frame.

\section{Result and discussion}

Ranging from modelling, entering parameters, and running programs on structural analysis programs, the results were the internal force's data including bending moment and axial force at the beams and columns that would be modelled on structural analysis programs. Reinforcement of flexural beams and columns was designed based on the internal force's data. Based on the theoretical results, the behavior of a concrete frame structure with infill wall has better ductility and capacity compared to that with the concrete open frame structure. Concrete frame structure with infill wall indicated better behavior in comparison to that with the concrete open frame structure.

The concrete frame is very stiff in the in-plane direction therefore when it is exposed to high seismic loads, there will be a crack in the diagonal direction that is accompanied by the reduction of strength and stiffness, and hence the diagonal reinforcement will be able to reduce the compressive force or tensile force diagonally. Retrofitting the diagonal reinforcement at the diagonal area is to prevent the occurrence of cracking when seismic forces are received by a concrete frame and the wall wobbles right and left. If the direction of the earthquake force is front to back, the diagonal reinforcement will hold back the material of the wall for it not to immediately collapse. This behavior is very important when an earthquake occurs, since it gives people more time to evacuate $t$ before more damage takes place.

Table 2. Compressive strength.

\begin{tabular}{|c|c|c|}
\hline Wall Type & $\begin{array}{c}\text { Compressive Strength } \\
\text { (MPa) }\end{array}$ & $\begin{array}{c}\text { Flexural Strength } \\
\text { (MPa) }\end{array}$ \\
\hline Concrete Frame & 0.664 & 0.660 \\
\hline Brick Wall without Bracing & 0.787 & 0.909 \\
\hline Brick Wall with Bamboo Bracing & 0.884 & 1.855 \\
\hline Brick Wall with Steel Bracing & 0.917 & 2.381 \\
\hline Panel wall without Bracing & 2.094 & 2.672 \\
\hline Panel wall with Bamboo Bracing & 2.264 & 3.246 \\
\hline Panel wall with Steel Bracing & 2.470 & 4.796 \\
\hline
\end{tabular}

Table 2 demonstrates that the compressive strength of open-frame is $0.644 \mathrm{MPa}$ and the compressive strength of brick wall without diagonal reinforcement is $0.787 \mathrm{MPa}$, which is $18.52 \%$ higher than that of open-frame. Furthermore, the compressive strength of brick wall with diagonal steel reinforcement is $0.917 \mathrm{MPa}$, meaning it is $38.10 \%$ higher than the compressive strength of the open frame and $16.52 \%$ higher than the compressive strength of brick wall without reinforcement. Meanwhile, bamboo contributes $33.13 \%$ in comparison to the compressive strength of brick wall without diagonal reinforcement.

The compressive strength of panel walls without diagonal reinforcement is $2.094 \mathrm{MPa}$ and has additional $215.36 \%$ of compressive strength. The compressive strength of panel 
walls with diagonal steel reinforcement is $2.470 \mathrm{MPa}$, which is $271.99 \%$ higher than the compressive strength of open-frame walls and $17.96 \%$ higher than the compressive strength of panel walls without reinforcement. Furthermore, Bamboo contributes $8.12 \%$ in comparison to the compressive strength of panel walls without diagonal reinforcement.

Table 2 also shows that the flexural strengths of the concrete frame structure and brick wall without diagonal reinforcement are $0.660 \mathrm{MPa}$ and $0.909 \mathrm{MPa}$, respectively, or in other words, the flexural strength of the second is $37.73 \%$ higher than that the first. Furthermore, the flexural strength of brick walls with steel diagonal reinforcement is 2.381 $\mathrm{MPa}$, which is $260.76 \%$ higher than the flexural strength of the open-frame brick wall, and $161.94 \%$ higher than the flexural strength of brick wall without diagonal reinforcement. Meanwhile, bamboo contributes $21.48 \%$ in comparison to the flexural strength of brick wall without diagonal reinforcement.

The flexural strength of panel walls without diagonal reinforcement is $2.672 \mathrm{MPa}$ and has additional $304.85 \%$ of flexural strength. The flexural strength of panel walls with diagonal steel reinforcement is $4.796 \mathrm{MPa}$, which is $626.67 \%$ higher than the flexural strength of open-frame walls and $79.49 \%$ higher than the flexural strength of panel walls without reinforcement. Furthermore, Bamboo contributes $21.48 \%$ in comparison to the compressive strength of panel walls without diagonal reinforcement.

Table 3. Brick wall capacity.

\begin{tabular}{|c|c|c|c|}
\hline $\begin{array}{c}\text { Type of } \\
\text { Test }\end{array}$ & Test objects & $\begin{array}{c}\text { Type of Test } \\
\text { Objects } \\
\end{array}$ & \begin{tabular}{|c|} 
Load Capacity \\
$(\mathrm{kN})$
\end{tabular} \\
\hline \multirow{4}{*}{$\begin{array}{l}\text { Frame } \\
\text { Structure } \\
\text { Capacity }\end{array}$} & $\begin{array}{l}\text { Concrete Open- } \\
\text { Frame Structure }\end{array}$ & $\begin{array}{c}\text { Concrete Frame } \\
\text { Structure }\end{array}$ & 6.0 \\
\hline & \multirow{3}{*}{$\begin{array}{l}\text { Brick Wall at } \\
\text { Concrete Frame } \\
\text { Structure }\end{array}$} & without bracing & 7.75 \\
\hline & & $\begin{array}{c}\text { with Bamboo } \\
\text { bracing }\end{array}$ & 9.86 \\
\hline & & with Steel bracing & 9.98 \\
\hline
\end{tabular}

Table 4. Panel wall capacity.

\begin{tabular}{|c|c|c|c|}
\hline $\begin{array}{c}\text { Type of } \\
\text { Test }\end{array}$ & Test objects & $\begin{array}{c}\text { Type of Test } \\
\text { Objects }\end{array}$ & \begin{tabular}{|c}
$\begin{array}{c}\text { Load Capacity } \\
(\mathrm{kN})\end{array}$ \\
\end{tabular} \\
\hline \multirow{3}{*}{$\begin{array}{c}\text { Frame } \\
\text { Structure } \\
\text { Capacity }\end{array}$} & \multirow{3}{*}{$\begin{array}{l}\text { Panel Wall at } \\
\text { Concrete Frame } \\
\text { Structure }\end{array}$} & without bracing & 28.87 \\
\hline & & $\begin{array}{c}\text { with Bamboo } \\
\text { bracing }\end{array}$ & 37.37 \\
\hline & & with Steel bracing & 43.9 \\
\hline
\end{tabular}

Table 5. Shear stiffness and ultimate shear strength of panel wall.

\begin{tabular}{|c|c|c|c|c|c|}
\hline $\begin{array}{c}\text { Type of } \\
\text { Test Objects }\end{array}$ & $\begin{array}{c}\text { Length } \\
(\mathbf{m m}) \\
\mathbf{A}\end{array}$ & $\begin{array}{c}\text { Wide } \\
\mathbf{( m m}) \\
\mathbf{b}\end{array}$ & $\begin{array}{c}\text { Deformation } \\
(\mathbf{m m}) \\
\mathbf{d}\end{array}$ & $\begin{array}{c}\mathbf{G} \\
\mathbf{( k N / m )}\end{array}$ & $\begin{array}{c}\mathbf{S}_{\mathbf{u}} \\
(\mathbf{k N} / \mathbf{m})\end{array}$ \\
\hline without bracing & 740 & 640 & 15.10 & 2210.4 & 45.10 \\
\hline with Bamboo bracing & 740 & 640 & 13.83 & 3123.27 & 58.39 \\
\hline with Steel bracing & 740 & 640 & 10.30 & 4920.13 & 68.59 \\
\hline
\end{tabular}

The load capacity that can be retained by the frame concrete structure without infill brick wall is $6 \mathrm{kN}$. After the installation of the brick wall into the frame structure, the load capacity is $7.75 \mathrm{kN}$, or in other words there is an increase of $29.177 \%$. At the diagonal area of the wall with diagonal reinforcement, the group reinforcement of bamboo contributes to the load capacity of $9.86 \mathrm{kN}$ while the reinforcement group of steel contributes to $9.98 \mathrm{kN}$ load capacity. Hence, the group of bamboo diagonal reinforcements contributes an increase 
by $27.23 \%$ in the capacity load, while the group of steel diagonal reinforcements contributes by $28.77 \%$ (Table 3 ).

Load capacity of the concrete frame structure with panel wall is $28.87 \mathrm{kN}$, or there is an increase of $381.17 \%$. By the addition of bamboo as diagonal reinforcement, the load capacity reaches $37.37 \mathrm{kN}$ or there is an increase of $29.44 \%$ in comparison to panel walls without bracing. Furthermore, the load capacity of panel walls reinforced with a group of steel is $43.9 \mathrm{kN}$, or there is an increase by $17.47 \%$ in comparison to the load capacity of panel walsl with bamboo reinforcement (Table 4).

Shear stiffness, $G^{\prime}$ analysis was performed based on laboratory data, referring to ASTM E564, $G^{\prime}=\frac{P}{d} \times \frac{a}{b}$. This stiffness analysis is carried out at load resistance where the wall has reached the maximum peak load. Ultimate shear strength, $\mathrm{S}_{\mathrm{u}}$ was also analyzed based on the results of laboratory testing, referring to ASTM E564, $S_{u}=\frac{P_{u}}{b}$ (Table 5).

Deformation occurs due to the combination of flexure failure and shear failure. The process is marked by the flexure pattern that will expand if the main reinforcement of column yielding occurs. Flexure deformation will cause double curvature formation, tension in a half span and compression in another half span that takes place at the upper and lower surfaces. Consequently, conflict in shear deformation occurs and causes tension at the surfaces of the column.

The major failure of brick walls and panel walls is shear failure, which is marked by the crack in a diagonal direction on the wall which is directly followed by the split in the path of the crack. The width of diagonal split on the wall with diagonal reinforcement can be reduced in comparison to the split on the wall without diagonal reinforcement. Furthermore, bamboo bracing in the pre-crack phase has better resistance to earthquakes in comparison to steel bracing, although in the post-crack phase steel materials have better behavior as bracing. This is due to the differences between the behavior of bamboo and steel stress-strain. Steel material is more ductile and has a good resistance in supporting the load even in the non-elastic phase. On the contrary, bamboo is brittle wherein the nonelastic phase, its ability to withstand the load is greatly reduced.

\section{Conclusions}

This study indicates that the diagonal reinforcement of steel bars and bamboo contributes to better capacity of concrete frames, particularly to withstand lateral loads. Walls with diagonal reinforcement of steel and bamboo are designed in the group of reinforcements that will serve as a concrete core, therefore it can withstand greater lateral loads and decrease the deflections. Characteristics of cracks in shear will occurs suddenly and has a diagonal crack patterns. Cracks at diagonal wall surfaces along the diagonal reinforcement indicate that the concrete core can reduce the split of the wall. The construction of a wall with a group of diagonal reinforcement bars can be an alternative to replace conventional walls, particularly in the construction of simple earthquake-safe buildings.

\section{References}

1. M. Holmes, Steel Frames with brickwork and concrete infilling, Proceedings of the Institution of Civil Engineers, 473-478, eISSN 1753-7789 (1961)

2. B. S. Smith, Lateral stiffness of infilled frames, Journal of the Structural Division, ASCE, Vol. 88, No. St-6., pp.183-199 (1962)

3. R. J. Mainstone, On the stiffnesses and strengths of infilled frames, Proceedings of the Institution of Civil Engineers, Supplement (V), pp. 57-90 (1971) 
4. J. L. Dawe, and C. K. Seah, Out-of-plane resistance of concrete masonry infilled panels, Canadian Journal of Civil Engineering, Vol. 16, No. 6 : pp. 865-876 (1989)

5. R. D. Flanagan, Richard Bennett, G. A. Barclay, Experimental testing of hollow clay tile infilled frames, Department of Civil and Environmental Engineering, University of Tennessee, Conference Paper · February (1992)

6. A. Saneinejad, B. Hobbs, Inelastic Design of Infilled Frames, Mgr., Struct. Engrg., San group Inc., vol.77 Alamosa Dr., North York, Ontario M2J 2N8, Canada, Published online: April 01 (1995)

7. Maidiawati, and Y. Sanada, Investigatian and Analysis of Building Damage during the September 2007 Sumatera Indonesia Earthquake. Journal of Asian Architecture and Building Engineering, vol.7(2), pp. 371-378 (2008)

8. R. Park, and T. Paulay, Reinforced Concrete Structure, Seventh Edition. John Willey \& Sons Inc. Canada (1975)

9. J.S. Mojca, G. Samo, B. Vlatko, and Z. Roko. Testing and analysis of walls strengthened with FRP. GRAĐEVINAR 66, vol.6, 533-548 (2014)

10. C. Marco, B. Antonio, C. Giulio, and S. Romina. Shear strengthening of wall panels through jacketing with cement mortar reinforced by GFRP grids. Composites Part $B$ Engineering, Elsevier, vol.64, 33-42 (2014)

11. A. Kalali, and M.Z. Kabir. Cyclic behavior of perforated masonry walls strengthened with glass fiber reinforced polymers. Scientia Iranica A, elsevier, vol.19 (2) 151-165 (2012)

12. B. Saman, D.C. Farsisco, and N. Antonio. URM Walls strengthening with fabricreinforced cementitious matrix composite subjected to diagonal compression. Journal Composite Construction, vol.18, ASCE (2014)

13. Z. Deyua, L. Zhen, and W. Jibing. In-plane behavior of seismically damage masonry walls repaired with external BFRP. Journal Composite Structure, elsevier, 102, 9-19 (2013)

14. L. Tong, G Nestore, T. Gustavo, and N. Antonio. Analysis of unreinforced masonry concrete walls strengthening with glass fiber-reinforced polymer bars. ACI Structural Journal, V, 102, No. 4, 569-576 (2005)

15. M. Enea, and Y. Yavuz. In-plane shear strengthening of unreinfoorced masonry walls using GFRP jacketing. Periodica Polytechnica Civil Engineering, vol.62 (2), pp. 330336 (2018)

16. S.H. Farooq, M. Ilyas, and A. Ghaffar. Technique for strengthening of masonry wall panels using steel strips. Asian journal of civil engineering (building and housing), Vol. 7, No. 6 (2006)

17. D. Key, Earthquake Design Practice for Building. London: Thomas Telford (1988)

18. Y. Nurchasanah, Ductility Behaviour of Reinforced Concrete Coupling Beams with Diagonal Reinforcement between Deform types with CRT Bar Type, Journal Gelagar, Engineering Faculty - UMS, Vol. 17 No.02 (2006)

19. Y. Nurchasanah, Force Distribution in the main bars of Reinforced Concrete Coupling Beams with Diagonal Reinforcement, Journal EcoRekayasa, Post Graduate School UMS, Vol. 3, No. 2 (2007) 